\title{
INCIDENCE OF "RHEUMATOID FACTORS" IN AGED SERUM
}

\author{
BY \\ J. J. DE BLÉCOURT, F. WESTENDORP BOERMA, AND E. O. VORENKAMP \\ Rheumatism Unit and Bacteriological-Serological Department, University of Groningen, The Netherlands
}

Heimer, Levin, and Rudd (1963) found a positive latex-fixation test in 42 per cent. and a positive sensitized sheep cell test in 2 per cent. of 121 persons aged 65 to 93 years in a home for the aged in New York City.

Although these "rheumatoid factors" are sometimes found in non-rheumatoid sera, those found in older people seem to be the same as those found in patients with rheumatoid arthritis.

In a control study of fifty healthy subjects under 65 years of age they found an incidence of 4 per cent. for the latex-fixation test and 2 per cent. with the sensitized sheep cell test. Their 121 aged subjects included no cases of liver disease, syphilis, leprosy, or bacterial endocarditis, and rheumatoid arthritis was also excluded. Nearly 50 per cent. of the positive latex-fixation titres (method of Singer and Plotz, 1956) were $1: 640$ or above.

Heimer and others (1963) could not explain the increased incidence of rheumatoid-like serum factors among the aged, but suggested that a piling-up of auto-antibodies or a decreased production of certain serum components might be responsible, and gave a warning against reliance on serological tests in the diagnosis of rheumatoid arthritis in elderly persons.

Litwin and Singer (1965) found an incidence of 30 per cent. of anti-gamma globulin factor in the sera of ninety persons over 70 years of age irrespective of the presence or absence of chronic illness.

Kissick (1961) mentioned an incidence of seropositivity rising from $4 \cdot 7$ per 1,000 in the 15 to 24 year age group to $42 \cdot 2$ per 1,000 in those over 65 .

Blumberg, Block, Black, and Dotter (1961), in a survey of the healthy Eskimo population in Alaska, found an increasing number of positive Bentonite flocculation tests with age.

Jacqueline, Podliachouk, and Eyquem (1965) studied 248 persons over 70 years of age and 270 persons under 70 years of age by the modified Waaler-Rose test, the latex-fixation test, and a haemagglutination reaction with $\mathrm{O}$ Rh-positive human cells sensitized with anti-Rh serum. The incidence of rheumatoid factor was 27 per cent. in the aged and $4 \cdot 1$ per cent. in the adult control group. In the aged, the Waaler-Rose test was positive in 12.5 per cent., the latex-fixation test in 10.9 per cent., and the haemagglutination test with $\mathrm{O}$-cells sensitized with anti-Rh serum in 12.5 per cent. The frequency of positive reactions rose abruptly between 70 and 80 years. Eighteen aged persons had two or three reactions positive.

Bunim, Burch, and O'Brien (1964) found about the same distribution of positive sensitized sheep cell agglutination tests in all age groups of Indian tribes in Arizona and Montana, with a definite increase with age of positive Bentonite flocculation tests in the Montana tribe only.

Waller, Toone, and Vaughan (1964) reported a significant increase in sero-positivity with advancing age, with relatively low titres. In a group of 84 persons aged from 64 to 90 years, $16 \cdot 7$ per cent. had a positive sensitized human cell agglutination test and 29.8 per cent. a positive latex slide test.

Baum (personal communication) found no positive latex-fixation tests in forty aged persons, and in a previous investigation we found only 0.5 per cent. positive latex-fixation tests and 4 per cent. positive modified Waaler-Rose tests in 250 healthy persons over 60 years old.

Valkenburg stated that, in many European countries, where similar serological studies are performed, the latex-fixation test gives a slightly higher incidence of "false-positives" than the sensitized sheep or human cell agglutination tests. In some tropical areas also an excess of positive latex-fixation tests has been found; this could be partially correlated with the nutritional status.

Litwin and Singer (1965) found a higher incidence of sero-positivity in institutionalized than in noninstitutionalized persons aged 50 to 70 years. 
Some authors suggest that sero-positivity is more frequent in urban than rural populations.

Because these earlier observations are sometimes contradictory we have carried out an investigation similar to that of Heimer and others (1963).

\section{Material and Methods}

Subjects.-A serum specimen was obtained from fifty male and fifty female inhabitants of an urban old age home, and 45 male and fifty female inhabitants of a rural old age home. Those with objective signs and symptoms of rheumatoid arthritis were excluded. They ranged in age from 65 to over 90 years of age. They were examined for evidence of disease, and some were found to be suffering from ailments common to this age group but were not hospitalized or on the "sicklist".

\section{Results}

These are shown in Table I.

\section{Serological Tests}

Latex-fixation Test.-This was performed by the method of Singer and Plotz (1956). Agglutination of latex particles at serum dilations of $1: 20$ or over was considered to be a positive result.

Modified Waaler-Rose Test.-This was performed with sensitized human erythrocytes as described in former publications from our laboratory; dilutions of $1: 16$ or over were considered to be positive.

Heimer and others (1963) found a sero-positivity of 46 per cent. ( 56 of 121) with the Hyland RA slide test, and of 42 per cent. (51 of 121) with the latexfixation test. In 50 per cent. of their positive latexfixation tests the titre was $1: 160$ or less. Their total percentage of sero-positivity with the latexfixation test is thus about five times higher than ours. We found the same trend towards higher seropositivity in persons of 75 to 84 years of age, as mentioned by Heimer and also by Jacqueline and others (1965) and Litwin and Singer (1965), but we found no decline in sero-positivity in people above age 85 .
With the Waaler-Rose test we found no differences in the incidence in the different age groups. In fifteen of the seventeen positive tests the titre was only $1: 16$ or $1: 32$, the other two being $1: 128$ and $1: 256$. In seven cases the Waaler-Rose test and the latex-fixation test were both positive, and these included the two cases with high Waaler-Rose titres. These persons showed no signs of clinical rheumatoid arthritis or other collagen disease.

The results are shown according to the urban and rural environment of the subjects in Table II. There is a tendency for the incidence of seropositivity to be lower in the rural group.

TABLE II

RESULTS BY SEX AND ENVIRONMENT

\begin{tabular}{c|c|c|l|c}
\hline Situation & $\begin{array}{c}\text { No. of } \\
\text { Cases }\end{array}$ & Sex & \multicolumn{1}{c|}{ Test } & $\begin{array}{c}\text { Percentage } \\
\text { Positive }\end{array}$ \\
\hline Urban & 50 & M & $\begin{array}{l}\text { Waaler-Rose } \\
\text { Latex }\end{array}$ & 10 \\
\cline { 2 - 4 } & 50 & F & $\begin{array}{l}\text { Waaler-Rose } \\
\text { Latex }\end{array}$ & 14 \\
\hline Rural & 45 & M & $\begin{array}{l}\text { Waaler-Rose } \\
\text { Latex }\end{array}$ & $\begin{array}{l}10 \\
7\end{array}$ \\
\hline Total & 50 & F & $\begin{array}{l}\text { Waaler-Rose } \\
\text { Latex }\end{array}$ & $\begin{array}{l}2 \\
6\end{array}$ \\
\hline 95 & M & $\begin{array}{l}\text { Waaler-Rose } \\
\text { Latex }\end{array}$ & $\begin{array}{l}9 \cdot 5 \\
8 \cdot 5\end{array}$ \\
\hline 100 & F & $\begin{array}{l}\text { Waaler-Rose } \\
\text { Latex }\end{array}$ & $\begin{array}{l}8 \\
8\end{array}$ \\
\hline 195 & Both & $\begin{array}{l}\text { Waaler-Rose } \\
\text { Latex }\end{array}$ & $\begin{array}{l}8 \cdot 7 \\
8 \cdot 2\end{array}$ \\
\hline
\end{tabular}

\section{Discussion}

In a former investigation of non-institutionalized elderly persons (de Blécourt and Boerma, 1963), 4 per cent. positive (modified) Waaler-Rose tests and 0.5 per cent. positive latex-fixation tests were detected. Our percentages in the present series of institutionalized subjects are higher $(8 \cdot 8$ and $8 \cdot 2$ per cent.), but the wide difference between our results

TABLE I

RESULTS OF PRESENT STUDY COMPARED WITH THOSE OF HEIMER AND OTHERS (1963)

\begin{tabular}{|c|c|c|c|c|c|}
\hline \multirow{2}{*}{$\begin{array}{c}\text { Age } \\
\text { (yrs) }\end{array}$} & \multicolumn{3}{|c|}{ Groningen } & \multicolumn{2}{|c|}{ New York (Heimer) } \\
\hline & $\begin{array}{l}\text { Number } \\
\text { of Cases }\end{array}$ & Waaler-Rose & Latex & $\begin{array}{l}\text { Number } \\
\text { of Cases }\end{array}$ & $\begin{array}{c}\text { Hyland RA } \\
\text { Slide Test }\end{array}$ \\
\hline $\begin{array}{l}65-69 \\
70-74 \\
75-79 \\
80-84 \\
85 \text { or more }\end{array}$ & $\begin{array}{l}42 \\
42 \\
45 \\
41 \\
25\end{array}$ & $\begin{array}{l}5 \\
1 \\
6 \\
1 \\
4\end{array}$ & $\begin{array}{l}3 \\
1 \\
3 \\
6 \\
3\end{array}$ & $\begin{array}{r}6 \\
26 \\
31 \\
35 \\
18\end{array}$ & $\begin{array}{r}1 \\
9 \\
21 \\
17 \\
8\end{array}$ \\
\hline Total & 195 & 17 & 16 & 116 & 56 \\
\hline
\end{tabular}


and those of Heimer and certain other investigators remains unexplained.

We tested the possibility of differences in laboratory techniques by the investigation of nine sera kindly sent to us by Dr. Heimer, but our results with these sera were the same as his.

From a recent personal communication from Valkenburg we learn that he has found, in another rural part of the Netherlands, a normal (low) percentage of "false-positive" latex-fixation tests in aged persons.

Close co-operation with the standardization of clinical and laboratory methods in internationally recognized reference-laboratories on a world-wide scale will be necessary to solve the problems raised by these "geographical" differences in the epidemiology of sero-positivity.

\section{Summary}

Of 195 inhabitants of two old-age institutions, $8 \cdot 8$ per cent. showed a positive Waaler-Rose test and $8 \cdot 2$ per cent. a positive latex-fixation test, which is a very much lower incidence than that found in a similar series of aged persons by other investigators.

\section{REFERENCES}

Blécourt, J. J. de, and Westendorp Boerma, F. (1963). Ann. rheum. Dis., 22, 429, 431.

Blumberg, B. S., Bloch, K. J., Black, R. L., and Dotter, C. (1961). Arthr. and Rheum., 4, 325.

Bumin, J. J., Burch, T. A., and O'Brien, W. M. (1964). Bull. rheum. Dis., 15, 349.

Heimer, R. Personal communication.
Heimer, R., Levin, F. M., and Rudd, E. (1963). Amer.J. Med., 35, 175.

Jacqueline, F., Podliachouk, L., and Eyquem, A. (1965). Ann. Inst. Pasteur, 109, Suppl. to No. 5, p. 48.

Kellgren, J. H. (ed.) (1963). "The Epidemiology of Chronic Rheumatism". Blackwell, Oxford.

Kissick, W. L. (1961). Arthr. and Rheum., 4, 424.

Litwin, S. D., and Singer, J. M. (1965). Ibid., 8, 538.

Singer, J. M., and Plotz, G. M. (1956). Amer. J. Med., 21, 888 .

"Transactions of the First International Conference on Population Studies in Rheumatoid Arthritis, 1957' (1958). Bethesda, Md.

Valkenburg, H. A. Personal communication.

Waller, M., Toone, E. C., and Vaughan, E. (1964). Arthr. and Rheum., 7, 513.

\section{Fréquence des "facteurs rhumatoïdes"} dans le sérum des sujets âgés

\section{RÉSUMÉ}

Parmi les 195 pensionnaires de deux maisons de vieillards 8,8 pour sent présentèrent une réaction de Waaler-Rose positive et 8,2 pour cent un test au latex positif, ce qui constitue une fréquence très inférieure à celle observée dans des groupes identiques de personnes âgées par d'autres investigateurs.

\section{Incidencia de "factores reumatoides" en el suero de los ancianos}

\section{SUMARIO}

De 195 habitantes de dos asilos de ancianos, un 8,8 por ciento presentó una reacción de Waaler-Rose positiva y un 8,2 por ciento una reacción con latex positiva, lo que representa una incidencia mucho más baja que la encontrada en grupos similares de ancianos por otros investigadores. 